\title{
PHYTOCHEMICAL SCREENING AND ANTIMICROBIAL EFFECT OF THE AQUEOUS AND METHANOLIC EXTRACTS OF ROOTS OF Balanites aegyptiaca (Del.) ON SOME BACTERIA SPECIES.
}

\author{
*HENA, J. S⒈, ADAMU, A.. K¹., IORTSUUN, D. N¹. \& \\ OLONITOLA, O. S².
}

\author{
${ }^{1}$ Department of Biological Sciences, Ahmadu Bello University, \\ Zaria, Nigeria. \\ 2Department of Microbiology, Ahmadu Bello University, Zaria, \\ Nigeria \\ *iayhena@yahoo.com
}

\section{INTRODUCTION}

Traditional medicine is the oldest method of curing diseases and infections and various plants have been used in different parts of the world to treat human diseases and infections (Caceres et al., 1991 Nweze et al., 2004, Vineela \& Elizabeth, 2005). Different plant parts have also been used for the treatment of various form ailments. The Balanites aegyptiaca plants have been reported to be used in a variety of folk medicines in Africa and Asia. It has been used in the treatment of skin diseases and remedy for stomach ache and jaundice (Hammiche \& Maiza, 2006), treatment of cough (John et al., 1990), treatment of diarrhea and syphilis (Boulos, 1992) and Typoid fever (Doughari et al., 2007) The root was also reported to be used in treatment of inflammation (Kubmarawa et al., 2007) antidote for snake bite (Inngerdigen, 2004). Earlier studies have shown that $B$. aegyptiaca contains steroidal saponins, with most of them reporting the presence of saponins as the main cause of these activities. Besides its medicinal uses, Balanites trees are widely used as fodder and for timber purposes (Arbonier, 2002). Medicinal plants are known to owe their curative potentials to certain biological active substances which exist in parts of the plants. The chemicals which are referred to as active principles or phytochemical substances include terpenses, flavonoid, bioflavonoid, benzophonones, xanthenes as well as some metabolites such as tannins, saponins, cyanates, oxalate and anthrax- quinones (Iwu, 1993; Asaolu, 2002). This study is therefore aimed at determining the antimicrobial efficacy of the aqueous and the methanolic extracts of Balanites aegyptiaca.

Collection of plant material: The leaves and roots of Balanites aegyptiaca were collected in the wild in Zaria (latitude 11.07N and longitude 4.28E) and taken to the herbarium of the Department of Biological Sciences, Ahmadu Bello University Zaria and identified with voucher number 900175 .

Preparation of extracts: After shade drying the plant material was grounded into powder using pestle and mortar. Exposure to sunlight was avoided to prevent the loss of active components (Thakare, 2004).

Extraction of plant materials by maceration method: One liter of $80 \%$ methanol extraction fluid was mixed with $200 \mathrm{~g}$ of powdered plant material. The mixtures were kept for 2 days in tightly sealed vessels at room temperature and stirred several times daily with a sterile glass rod. This mixture was filtered through muslin cloth. Further extraction of the residue was repeated 3-5 times until a clear colorless supernatant extraction liquid was obtained indicating that no more extraction from the plant material was possible. The extracted liquid was subjected to water bath evaporation to remove the solvent. The water bath temperature was adjusted to $40^{\circ} \mathrm{C}$. The same procedure was used for the aqueous extract. The semi-solid extract produced was kept under a ceiling fan to dry. The extract was weighed and portion of it used for phytochemical screening while the rest was use for the susceptibility test.

Phytochemical screening: Standard phytochemical test was carried out on the plant samples using the method of Trease and Evans (1989) to determine presence of Alkaloids, flavonoids, glucosides, saponim, tannins, phlobatannins, anthroquinone, steroids and terpenoids.

Antimicrobial susceptibility studies: Inhibition of microbial growth was tested by using the well method (Kirby-Bauer Method as described by Drago et al., 1999). Standard aseptic microbiological methods were followed throughout this antibacterial study.

Test Organisms: Clinical strains of Pseudomonas auregenosa, Staphylococcus aureus, Salmonella typhi, Escherichia coli and Candida albicans were obtained from Department of Microbiology, Ahmadu Bello University, Zaria, Nigeria.

McFarland Standard: 0.5 McFarland standard was prepared adding $0.5 \mathrm{ml}$ of $1 \%$ Barium chloride $\left(\mathrm{Bacl}_{2}\right.$ ) to $99.5 \mathrm{ml}$ of $1 \%$ sulphoric acid $\left(\mathrm{H}_{2} \mathrm{SO}_{4}\right)$ solution. The turbidity (density) of the 0.5 McFarland standard was used for estimation of the amount of bacteria in broth culture (culture for 24 hours at $37{ }^{\circ} \mathrm{C}$ ) to pour into $5 \mathrm{ml}$ of distilled water in order to obtain a standard bacterial suspension of $1 \times 10^{8}$ bacterial cells $\mathrm{m}$ (Bauer et al., 1986).

Serial Doubling Dilution: Stock solution was prepared using $1 \mathrm{~g}$ of the solid plant extract dissolved in $10 \mathrm{mls}$ of normal saline making a stock of $100 \mathrm{mg} / \mathrm{ml}$. Serial doubling dilution was employed to obtain concentrations of $100 \mathrm{mg} / \mathrm{ml}, 50 \mathrm{mg} / \mathrm{ml}$, $25 \mathrm{mg} / \mathrm{ml}, 12.25 \mathrm{mg} / \mathrm{ml}, 6.125 \mathrm{mg} / \mathrm{ml}$ and $3.125 \mathrm{mg} / \mathrm{ml}$ respectively.

Well method for antibacterial activity: The well method was employed to assay the plant extracts for antimicrobial activity. Petri dishes were plated with Muller - Hinton agar and prepared according to the manufacturers manual was allowed for 30 minutes to solidify. The test organisms were then spread on the surface of the media using a sterile swap stick. Cork borer (3mm) was used to bore wells in the media, six/petri-dish. The different concentration of the plant extracts were dispensed into the wells using a sterile syringe and needle. These were then allowed a diffusion time of 1 hour after which it was incubated at $37^{\circ} \mathrm{C}$ for 24 hour. Zones of inhibition were measured using a metre rule and the mean recorded in millimeter as described by Mukherjee et al., (1995).

Minimum Inhibitory Concentration (MIC): The aqueous and methanolic extracts which showed significant zones of inhibition were chosen to assay for MIC. MIC was determined by the standard method of Wariso and Ebong (1996). Nutrient broth was prepared and sterilized using autoclave. One (1) $\mathrm{ml}$ of the prepared broth was dispensed in to the test tubes numbered 1-9 
using sterile syringe and needle. A stock solution containing $25 \mathrm{mg} / \mathrm{ml}$ of the extract was prepared. Then $1 \mathrm{ml}$ of the solution was dispensed into the tubes numbered 1 . Subsequently, from tube 1 , serial dilution was carried out and $1 \mathrm{ml}$ from tube 1 was transferred up to tube number 7 and $1 \mathrm{ml}$ from the tube 7 was discarded. Tube 8 was control for sterility of the medium and tube 9 for viability of the organisms. An overnight culture (inoculums) of each of the test isolates was prepared in sterile nutrient broth. $1 \mathrm{ml}$ of the inoculum was transferred into each tube from tube 1 to tube 9 with exception of tube 8, to which another sterile nutrient broth was added. The final concentration of the plant extract in each of the test tubes numbered 1-7 after dilution $25,12.5,6.25,3.125$, $1.563,0.78$ and $0.39 \mathrm{mg} / \mathrm{ml}$, were incubated at $37^{\circ} \mathrm{C}$ for $24 \mathrm{~h}$ and examined for growth. The last tube in which growth failed to occur was the MIC tube.

The preliminary phytochemical screening of the roots $B$. aegyptiaca indicated the presence of tannins, flavonoids, saponins, triterpenes and glycosides were identified in the plant extracts while alkaloids and steroids were found to be absent from the two extracts as shown in table 1 below. The antimicrobial activities of the root aqueous extract against $E$. coli, S. aureus, $P$. aureginosa, S. typhi and C. albicans is presented in Fig. 1 where all the test organisms were inhibited at

\section{TABLE 1. QUALITATIVE PHYTOCHEMICAL SCREENING OF AQUEOUS AND METHANOLIC EXTRACTS OF ROOTS OF B. aegyptiaca.}

\begin{tabular}{lcc}
\hline Phytochemical & $\begin{array}{l}\text { Methanolic } \\
\text { extract }\end{array}$ & $\begin{array}{l}\text { Aqueous } \\
\text { extract }\end{array}$ \\
\hline Alkaloid & - & - \\
Tannins & + & + \\
Flavonoids & + & + \\
Saponins & + & + \\
Steroids & - & - \\
Triterpenes & + & + \\
Glycosides & + & + \\
Anthroquonones & + & - \\
\hline + = Present, & $-=$ Absent
\end{tabular}

different concentrations except $S$. typhi which was not inhibited even at the highest concentration of $100 \mathrm{mg} / \mathrm{ml}$. Similarly, methanolic extract showed significant zones of inhibition on all the test organisms. C. albicans had the highest zone of inhibition at $50 \mathrm{mg} / \mathrm{ml}$ (Fig 2).

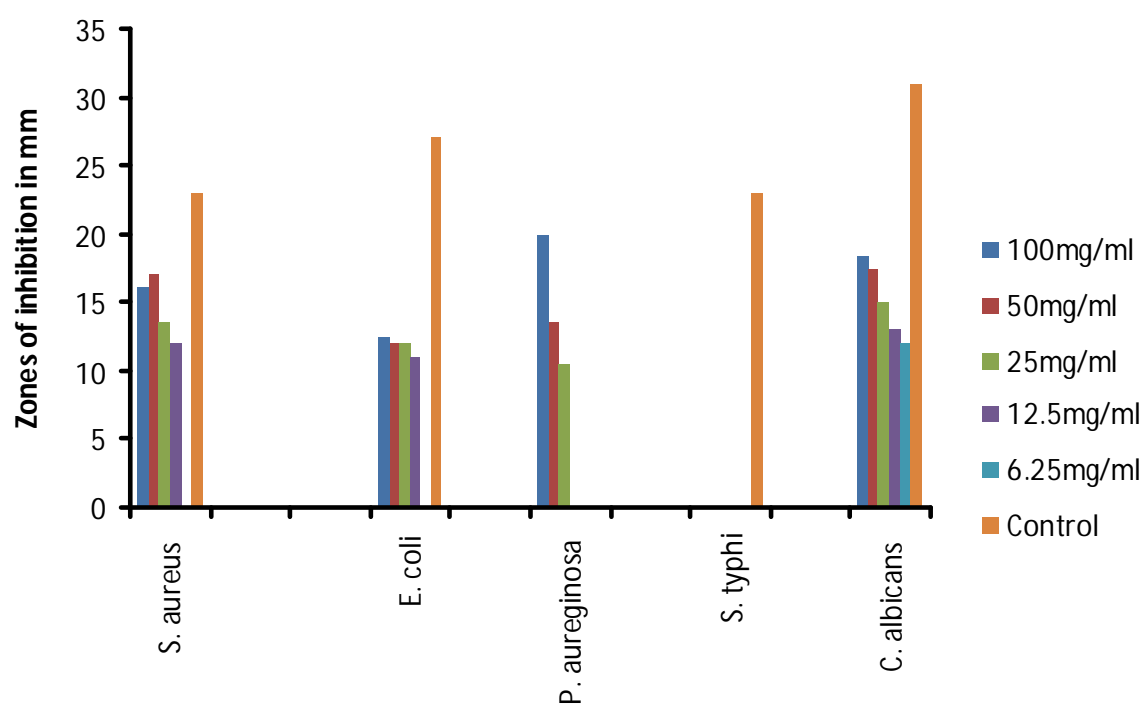

Microorganisms

FIG. 1. SENSITIVITY OF DIFFERENT MICROORGANISMS TO DIFFERENT CONCENTRATION OF AQUEOUS EXTRACT OF B. aegyptiaca.

The methanolic root extract indicated the highest and least MIC of $50 \mathrm{mg} / \mathrm{ml}$ and $1.563 \mathrm{mg} / \mathrm{ml}$ against S. typhi and C. albicans respectively while that of the aqueous extract ranged between $3.125-12.5 \mathrm{mg} / \mathrm{ml}$ as shown in (Table 2).

The presence of phytochemicals in the root of Balanites aegyptiaca observed in this study confirmed the presence of flavonoid, saponins, tannins and glycoside Alkaloid, and steroids were absent in both extracts. Anthroquinone was present in the methanolic extract but absent in the aqueous extract. This difference can be attributed to the solubility of the active component in different solvents (Ekpo \& Etim, 2009). This was in agreement with the work of Kubmarawa et al., (2007), who reported the presence of same in the root ethanolic extract of Balanites aegyptiaca. To a large extent, the chronological age of the plant, percentage humidity of the harvested material, situation and time of harvest, and the method of extraction were possible sources of variation for the chemical composition, toxicity and bioactivity of the extracts (Felix, 1982). The presence of these constituents has been reported to account for the exertion of antimicrobial activity by plants (Clark, 1981, Pretorius \& Watt, 2001). 


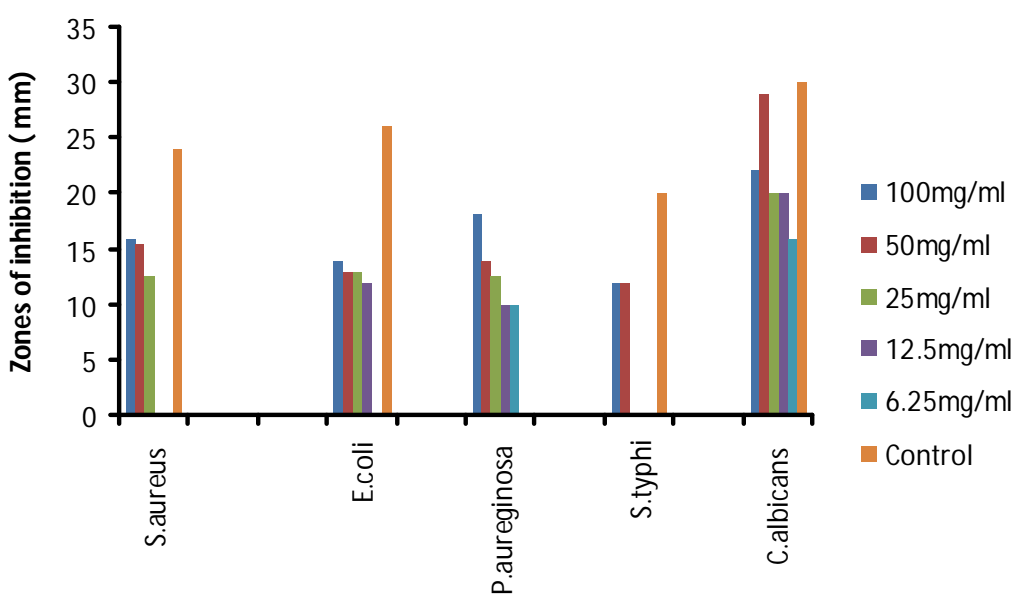

Microorganisms

FIG. 2. SENSITIVITY OF DIFFERENT MICROORGANISMS TO DIFFERENT CONCENTRATION OF METHANOLIC EXTRACT OF B. aegyptiaca.

TABLE 2. MIC OF THE AQUEOUS AND METHANOLIC EXTRACTS OF B. aegyptiaca ON THE TEST ORGANISMS.

\begin{tabular}{lll}
\hline Microorganisms & $\begin{array}{l}\text { Methanolic } \\
\text { extract }\end{array}$ & $\begin{array}{l}\text { Aqueous } \\
\text { extract }\end{array}$ \\
\hline S. aureus & 6.25 & 3.125 \\
E. coli & 3.135 & 6.25 \\
P. aureginosa & 3.125 & 12.5 \\
S. typhi & 50 & - \\
C. albicans & 1.563 & 3.125 \\
\hline
\end{tabular}

Methanolic extract of Balanites aegyptiaca showed significant zones of inhibition of the microorganisms used in the study. The aqueous extract was not able to inhibit S.typhi. This was in contrast with the result of Doughari et al., (2007) who reported activity of aqueous root extract of Balanite aegyptiaca on S. typhi even though the methanolic and acetone extract performed significantly better. These disparities may be attributed to the change in environmental conditions which may affect the production of secondary metabolite in the plant (Waterman \& Mole, 1989). There was no significant difference $(p>0.05)$ in the zone of inhibition between the two extract. The ability of $B$. aegyptiaca showing sensitivity to two different strains of bacteria (gram positive and gram negative bacteria) and fungi shows its application as a broad spectrum antimicrobial agent with the largest efficacy being the methanolic extract from this study. This justifies the use of this plant in traditional medicine practices. It is therefore recommended that more work be conducted to help optimally extract all the bioactive compounds in the plant and formulated into appropriate dosage for the treatment of infectious diseases.

\section{REFERENCES}

Arbonier, M. (2002). Trees, Shrub and Lianas of West African dry zones. The Netherlands: Girad Margraf Publishers.

Asaolu, M. F. (2003). Chemical composition and phytochemical screeningof the seeds of Garcinia kola. Pakistan Journal of Science \& Industrial Research. 46: 145-147

Bauer, A. W., Kirby, M. D. K., Sherras, J. C. \& Trick, M. (2003). Antibiotic susceptibility testing by standard single disc diffusion method. American journal of clinical pathology 45:4-496.
Boulos, L. (1992). Medicinal Plants of North Africa. Reference Publication Inc.

Caceres, A. L., Lopez, B. R., Giron, M. A., Logemann, H. (1991). Plants used in Guatemala for the treatment of dermatophytic infection in Screening for antimycotic activity of 44 plant extracts. Journal of Ethnopharmacology. 31:263-276.

Clark, W. S. (1981). Antimicrobial activities of phenolic constituents of Magnolia grandiflora L. Journal of Pharmaceutical. Science. 70: 951-952.

Doughari, J. H., Pukuma, M. S. \& De, N. (2007) Antibacterial effects of Balanites aegyptiaca L. Drel. and Moringa oleifera Lam. on Salmonella typhi. African Journal of Biotechnology. 6 (19), pp. 2212-2215,

Drago, L., B. Mombelli, G. Ciardo, E. De Vecchi \& Gismondo M. R. (1999). Effects of three different fish oil formulations on Helicobacter pylori growth and viability in in- vitro study. Journal of Chemotherapy. 11:207-21

Ekpo, M. A. \& Etim, P. C. (2009). Antimicrobial activity of ethanolic and aqueous extracts of Sida acuta on microorganisms from skin infections. Journal of Medicinal Plants Research, 3(9), 621-624.

Felix, M.T. (1982). Medical Microbiology. Churchill Livingstone (Publishers): London, UK.

Hammiche, H. \& Maiza, K. (2006). Traditional Medicine of Leaves in Sahara. Pharmacopocia of Tassili. Journal of ethnopharmacology. 105. 
Inngerdingen, K. C. S., Diallo, N. D. \& Mounkoro, B. S. (2004). An ethnopharmacological Survey of plants use for wound healing in Dogonland Mali West Africa. Journal of Ethnopharmacology. 92: 233-244.

Iwu, M. M. (1993). Handbook of African Medicinal plants. CRS Press Inc.Florida.

John, T., Kokwaro, J. O. \& Kimanani, E. K. (1990). Remedies of Luo of Siaya District, Kenya. Establishing quantitative criteria for census. Economic Botany. 44: (3) 369-381.

Kubmarawa, D., Ajoko, G. A., Enwerem, N. M. \& Okorie, D. A (2007). Preliminary phytochemical and antimicrobial screening of 50 medicinal plants of Nigeria. African Journal of Biotechnology. 6 :(14):1690-1696.

Mukherjee, P. K., Balsubramanian, R., Saha, K., Pal, M. \& Saha B. P. (1995). Antibacterial efficiency of Nelumbo nucifera (Nymphaeaceae) rhizome extract. Indian drugs, 32:274-276.

Nweze, E. L., Okafor, J. I. \& Njoku, O. (2004). Antimicrobial activities of methanolic extracts of Trema guinensis (Schumm and Thorn) and Morinda Lucida Benth used in Nigeria. Biological. Research. 2: 39-46
Pretorius, C.J. \& Watt, E. (2001). Purification and identification of active components of Carpobrotus edulis L. J. Ethnopharmacol. 76: $87-91$

Thakare, M. (2004) Pharmacological screening of some medicinal plants as antimicrobial and feed additive. Masters' Thesis. Department of Animal and Poultry Science, Virginia Polytechnic Institute and State University, Blackburg, Virginia, USA.

Trease,G. E. \& Evans W. C. (1989). A Textbook of Pharmacology, $13^{\text {th }}$ Ed. Ballieria T.nal Ltd. London.

Vineela, C. H. \& Elizabeth, K. M. (2005). Antimicrobial activity of marine algae of Visakhapatna city, Andhra Pradesh. Asian Journal of Microbiology, Biotechnology \& Environmental Science. 7: 209212.

Waterman, P.G. \& Mole, S. (1989) Entrinsic factors influencing production of secondary metabolites in plants. In: Bernays $E A(E d)$ Insect - plant interactions. CRC press, Boca Ranton, FL, Vol. 1:107-134. 